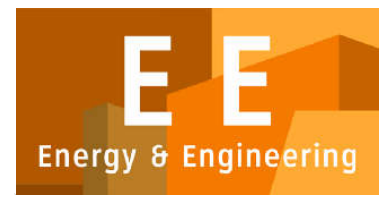

PAPER - OPEN ACCESS

\title{
Tinjauan Permintaan Gas Global dan Distribusi LPG di Indonesia: Studi Pustaka
}

\author{
Author $\quad$ : Juliza Hidayati dan Jeffrey Panama \\ DOI $\quad: 10.32734 /$ ee.v2i3.757 \\ Electronic ISSN $\quad: 2654-704 X$ \\ Print ISSN : $2654-7031$
}

Volume 2 Issue 3 - 2019 TALENTA Conference Series: Energy \& Engineering (EE)

\section{(ㅇ) $(19$}

This work is licensed under a Creative Commons Attribution-NoDerivatives 4.0 International License.

Published under licence by TALENTA Publisher, Universitas Sumatera Utara

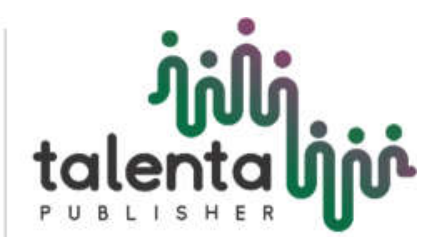




\title{
jibli talentaliois TALENTA Conference Series
}

\section{Tinjauan Permintaan Gas Global dan Distribusi LPG di Indonesia: Studi Pustaka}

\author{
Juliza Hidayati ${ }^{1}$, Jeffrey Panama ${ }^{2}$ \\ ${ }^{1,2}$ Program Studi Magister Teknik Industri dan Doktor Ilmu Teknik Industri Universitas Sumatera Utara, \\ Jl. Almamater, Kampus USU, Medan, Indonesia \\ ${ }^{1}$ rivaijuliza@gmail.com, ${ }^{2}$ jeffreypanama.usu@gmail.com
}

\begin{abstract}
Abstrak
Indonesia adalah negara yang kaya akan sumber daya alam. Sektor minyak bumi dan gas adalah sumber energi dan pendapatan utama Indonesia, yakni sekitar 25 hingga 30 persen dari permintaan energi nasional. Liquefied Petroleum Gas (LPG) adalah energi alternatif yang digunakan oleh masyarakat Indonesia dan seluruh dunia terutama untuk memenuhi kebutuhan energi rumah tangga, yang diproyeksikan akan meningkat selama beberapa periode berikutnya. Meningkatnya permintaan LPG akan berdampak pada proses distribusi saat ini yang meliputi fasilitas distribusi dan jaringan distribusi. Penyesuaian fasilitas distribusi dan jaringan distribusi, selain untuk memastikan keberlangsungan distribusi energi jangka panjang, juga diharapkan mampu memberikan biaya distribusi yang optimal bagi seluruh pelaku rantai pasok. Penelitian terdahulu yang menginterpretasikan permintaan gas global masih variatif, demikian juga dengan permintaan LPG di Indonesia. Selain itu, belum adanya studi yang mengkaji tentang fasilitas dan jaringan distribusi untuk memenuhi permintaan LPG Indonesia khususnya provinsi Sumatera Utara di masa depan. Oleh karena itu, penelitian ini berfokus pada penjabaran permintaan gas global dan fasilitas distribusi serta jaringan LPG di Indonesia untuk memenuhi permintaan energi nasional di masa depan. Pengumpulan data dilakukan dengan studi pustaka terhadap jurnal terkini terkait permintaan LPG dan distribusi LPG. Hasil studi pustaka membuktikan bahwa peningkatan permintaan gas terjadi di hampir seluruh dunia dalam memenuhi krisis energi global yang diproyeksikan akan terjadi hingga tahun 2050. Dalam hal distribusi LPG di Indonesia, selain menggambarkan faktor-faktor yang dapat mempengaruhi distribusi LPG di Indonesia, penelitian ini juga menjelaskan tahapan distribusi dari eksplorasi dan produksi hulu hingga LPG mencapai konsumen akhir.
\end{abstract}

Kata kunci: Krisis energi global, permintaan gas, kebutuhan masa depan, distribusi LPG, literature review.

\begin{abstract}
Indonesia is a country rich in natural resources. The oil and gas sector is Indonesia's main source of energy and income, which is around 25 to 30 percent of national energy demand. Liquefied Petroleum Gas (LPG) is an alternative energy used by the people of Indonesia and around the world, especially to meet household energy needs, which is projected to increase over the next several periods. The increasing demand for LPG will have an impact on the current distribution process which includes distribution facilities and distribution networks. Adjustment of distribution facilities and distribution networks, in addition to ensuring the long-term sustainability of energy distribution, is also expected to be able to provide optimal distribution costs for all supply chain actors. Previous research interpreting global gas demand is still varied, as is the demand for LPG in Indonesia. In addition, there are no studies examining the facilities and distribution networks to meet the demand for Indonesian LPG in the future province of North Sumatra. Therefore, this research focuses on elaborating global gas demand and distribution facilities and the LPG network in Indonesia to meet future national energy demand. Data collection was carried out with a literature study of the latest journals related to LPG requests and LPG distribution. The results of a literature study prove that the increase in gas demand occurs in almost the entire world in meeting the global energy crisis which is projected to occur until 2050. In terms of LPG distribution in Indonesia, in addition to describing the factors that can affect the distribution of LPG in Indonesia, this study also explains the distribution stage from exploration and upstream production to LPG reaches the final consumer.
\end{abstract}

Keywords: Global energy crisis, gas demand, future needs, LPG distribution, literature review.

(C) 2019 The Authors. Published by TALENTA Publisher Universitas Sumatera Utara

Selection and peer-review under responsibility of The 3nd National Conference on Industrial Engineering (NCIE)

2019

p-ISSN: 2654-7031, e-ISSN: 2654-704X, DOI: 10.32734/ee.v2i3.757 


\section{Pendahuluan}

Indonesia merupakan negara yang kaya akan sumber daya alam dan energi. Salah satu energi yang berperan signifikan dalam pertumbuhan energi global adalah gas alam, yakni sebesar 22\% energi dunia [1]. Dalam hal basis cadangan gas alam, Indonesia menempati posisi ke empat belas dunia. Hal ini diperkuat oleh fakta bahwa pada tahun 2014 Indonesia memegang cadangan gas alam sebesar $2.908 \mathrm{bcm} \mathrm{[2].} \mathrm{Meninjau} \mathrm{kebutuhan} \mathrm{dan} \mathrm{prospek} \mathrm{gas} \mathrm{di}$ Indonesia, konsumsi gas, energi tidak terbarukan (NRE), minyak, dan batubara diproyeksikan meningkat hingga tahun 2050. Pada tahun 2013, penggunaan gas dalam memenuhi kebutuhan energi nasional hanya sekitar 5\%, dimana didominasi oleh minyak (46\%), namun pada tahun 2025, konsumsi gas diperkirakan mencapai $23 \%$ dari energi nasional, dan mencapai $31 \%$ pada tahun 2050 [3].

Atas dasar pertimbangan besarnya subsidi minyak tanah, dan demi kesehatan yang lebih baik bagi pengguna, serta untuk efisiensi energi (1 liter kerosine setara dengan 0,39 kg LPG (World Bank, 2018), Pemerintah Indonesia meluncurkan program konversi minyak tanah (kerosine) ke LPG untuk memenuhi kebutuhan energi rumah tangga pada tahun 2004 [1]. Program konversi energi ini juga turut berkontribusi terhadap peningkatan permintaan gas LPG di Indonesia [4]. Data konsumsi LPG di Indonesia untuk tahun 2012 hingga 2016 tertera pada Tabel 1 di bawah ini.

Tabel 1. Konsumsi LPG di Indonesia Tahun 2012 hingga 2016

\begin{tabular}{cc}
\hline Tahun & $\begin{array}{c}\text { Konsumsi (metrik } \\
\text { ton) }\end{array}$ \\
\hline $\mathbf{2 0 1 2}$ & $5.079 .000,00$ \\
$\mathbf{2 0 1 3}$ & $5.607 .430,46$ \\
$\mathbf{2 0 1 4}$ & $6.093 .138,45$ \\
$\mathbf{2 0 1 5}$ & $6.376 .989,66$ \\
$\mathbf{2 0 1 6}$ & $6.677 .333,00$ \\
\hline
\end{tabular}

Permintaan LPG secara umum dipengaruhi oleh beberapa faktor. Penelitian terdahulu oleh Ravan pada tahun 2017 menunjukkan bahwa PDRB berpengaruh terhadap peningkatan LPG [4]. Peningkatan jumlah rumah tangga turut meningkatkan permintaan LPG [5]. Selain itu, variabel yang turut berpengaruh terhadap permintaan LPG adalah TPAK [6] dan laju inflasi [7].

Perubahan dan peningkatan demand (permintaan) akan berpengaruh terhadap pola distribusi perusahaan [8]. Perusahaan distribusi umumnya akan melakukan perencanaan strategis untuk melakukan penambahan fasilitas seiring dengan peningkatan permintaan [9]. Salah satu langkah strategis untuk melakukan ekspansi fasilitas adalah penambahan gudang yang dipandang sebagai suatu peluang untuk meningkatkan dan mengoptimasi penyaluran rantai pasok, mengurangi tingkat persediaan dan memungkinkan distribusi yang lebih responsif dan lincah [10].

Perancangan jalur distribusi umumnya dilakukan dengan mempertimbangkan beberapa kriteria yang umum digunakan dalam pemilihan jalur optimal. Penelitian Evaraert menunjukkan bahwa salah satu kriteria pemilihan jalur optimal adalah biaya distribusi [11]. Selain itu, kualitas permukaan jalan juga mempengaruhi waktu dan kelancaran suatu proses distribusi [12]. Faktor lain yang turut berpengaruh terhadap pengambilan keputusan jalur distribusi optimal adalah keramaian atau kepadatan jalan [13], keamanan selama perjalanan [14], [15], serta faktor kemudahan akses fasilitas sepanjang distribusi [16].

\section{Metodologi Penelitian}

Jenis penelitian yang dilakukan adalah studi pustaka dengan mengadakan studi penelaahan terhadap buku-buku, litertur-literatur, catatan-catatan, dan laporan-laporan yang ada hubungannya dengan masalah yang dipecahkan dimana bertujuan untuk mempelajari dan membaca literatur-literatur yang ada hubungannya dengan permasalahan yang menjadi objek penelitian [17]. Objek yang menjadi kajian studi pustaka adalah Liquefied Petroleum Gas (LPG) yang sudah menjadi kebutuhan setiap keluarga dan menjadi sumber energi utama dalam memenuhi kebutuhan rumah tangga di Indonesia. Studi pustaka ini memaparkan dan menjabarkan penelitian 10 tahun terakhir yang membahas tentang peramalan dan peninjauan kebutuhan LPG di seluruh dunia dalam memuhi krisis energi global dan distribusi LPG khususnya di Indonesia dalam memenuhi kebutuhan energi rumah tangga di Indonesia.

\section{Hasil dan Pembahasan}

\subsection{Fenomena Migas di Dunia}

Konsumsi gas global terjadi peningkatan dari tahun ke tahun. Faktor utama yang mendorong peningkatan konsumsi gas global pada tahun 2017 adalah lonjakan permintaan gas lebih dari 15\% di Tiongkok hingga mencapai 
$31 \mathrm{bcm}$ (sepertiga dari peningkatan konsumsi global) [18]. Namun, dengan konsumsi gas yang demikian besar pada Tiongkok, pada kenyataannya gas masih bukan pasokan energi terbesar untuk memenuhi kebutuhan industri yang kian meningkat, melainkan sumber energi di Tiongkok masih dikuasai oleh batubara, sekitar $67 \%$ dari total pasokan energi primer [19]. Konsumsi gas di Tiongkok diproyeksikan masih akan meningkat. Penelitian yang dilakukan oleh Junchen Li, dkk. meramalkan bahwa konsumsi gas di Tiongkok akan mengalami peningkatan hingga 198,2 bcm pada tahun 2020 sebelum mencapai 340,7 bcm pada tahun 2030 [20].

Meninjau kebutuhan gas di Eropa, juga terjadi peningkatan pada tahun 2017, yakni sebesar 26 bcm [18]. Peningkatan konsumsi gas di Eropa ini tidak hanya disebabkan oleh perindustrian, namun juga disebabkan oleh peningkatan konsumsi gas rumah tangga. Sebagai contoh, per tahun 2011, Britania Raya mendistribusikan gas kepada 22,9 juta konsumer eceran, dimana $84 \%$ diantaranya dialokasikan untuk kebutuhan rumah tangga melalui distribusi gas pipa (pipeline distribution) [21].

Pada Amerika Serikat, konsumsi gas justru terjadi penurunan sebesar 1,2\% pada tahun 2011 [18]. Hal ini disebabkan oleh karena upaya yang dilakukan Amerika Serikat dalam mengurangi emisi gas rumah kaca (Green House Gas), sehingga mendorong pemerintah berusaha mempromosikan energi alternatif pengganti bensin dan solar [22]. Kendati demikian, Energy Information Administration (EIA) di Amerika Serikat memprediksi bahwa akan terjadi peningkatan penggunaan gas secara jangka panjang di berbagai sektor, didorong oleh perkiraan peningkatan volume produksi gas dengan harga yang lebih rendah dibanding dengan energi lainnya. Dalam laporan EIA juga menunjukkan konsumsi gas di Amerika Serikat diproyeksikan meningkat hingga 25,7 tcf (sekitar 727,74 bcm) pada tahun 2030, dengan peningkatan terbesar diproyeksikan pada sektor transportasi yakni sekitar 0,13 tcf (sekitar 3,68 bcm) [23].

Bergerak ke Timur Tengah, konsumsi gas mengalami peningkatan sebesar 28 bcm pada tahun 2017 [18]. Konsumsi gas di Turki diproyeksikan mencapai 2.153 bcf (sekitar 60,99 bcm) pada akhir tahun 2018 [24]. Sedangkan di Iran, gas justru menjadi sumber energi utama yakni sekitar 48\%, bertepatan bertolak belakang dengan Tiongkok, batubara yang kini masih sumber energi utama Tiongkok hanya berkontribusi sekitar $1 \%$ bagi sumber energi nasional di Iran [25]. Berikut pada Gambar 1 disajikan pemetaan konsumsi LPG dunia berdasarkan volume konsumsi.

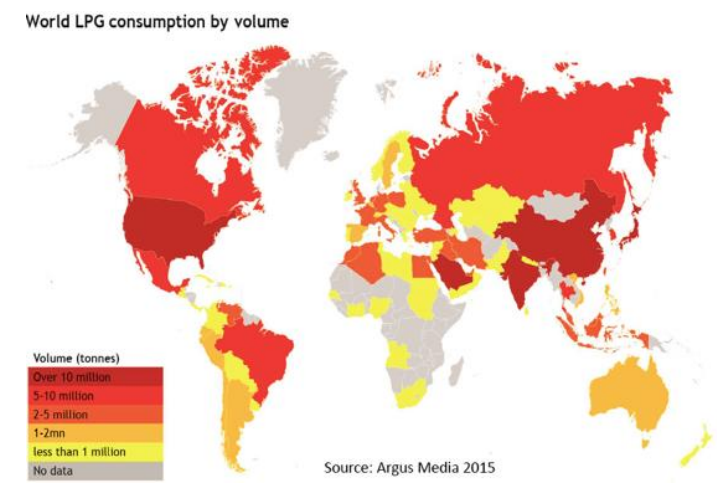

Gambar 1. Pemetaan Komsumsi LPG Dunia Berdasarkan Volume (Tahun 2015)

Sebagai pembanding yang memiliki letak geografis dengan latar belakang sejarah dan perkembangan kebudayaan yang mirip dengan Indonesia, kebutuhan energi Malaysia sebesar 32,11\% berasal dari gas, 46,04\% dari energi terbarukan, 18,92\% berasal dari batubara, PLTA sebesar 2,56\%, dan biomassa sebesar 0,14\% [26].

\subsection{Fenomena Migas di Indonesia}

\subsubsection{Landasan Hukum dan Regulasi Terkait Migas}

Sesuai dengan amanah Pasal 33 UUD 1945, dimana ayat ke (3) berbunyi "Bumi dan air dan kekayaan alam yang terkandung di dalamnya dikuasai oleh negara dan dipergunakan untuk sebesar-besar kemakmuran rakyat." Serta ayat ke (2) berbunyi "Cabang-cabang produksi yang penting bagi negara dan yang menguasai haja hidup orang 
banyak dikuasai oleh negara”. Maka sektor migas di Indonesia didominasi oleh Pertamina, yang merupakan salah satu Badan Usaha Milik Negara dibawah naungan Kementerian BUMN.

Berdasarkan Peraturan Pemerintah Republik Indonesia No. 36 Tahun 2004 tentang Kegiatan Usaha Hilir Minyak dan Gas Bumi, kegiatan usaha hilir pada sektor migas meliputi:

1. Kegiatan usaha Pengolahan yang meliputi kegiatan memurnikan, memperoleh bagian-bagian, mempertinggi mutu, dan mempertinggi nilai tambah Minyak dan Gas Bumi yang menghasilkan Bahan Bakar Minyak, Bahan Bakar Gas, Hasil Olahan, LPG dan/atau LNG tetapi tidak termasuk Pengolahan Lapangan;

2. Kegiatan usaha Pengangkutan yang meliputi kegiatan pemindahan Minyak Bumi, Gas Bumi, Bahan Bakar Minyak, Bahan Bakar Gas, dan/atau Hasil Olahan baik melalui darat, air, dan/atau udara termasuk Pengangkutan Gas Bumi Melalui Pipa dari suatu tempat ke tempat lain untuk tujuan komersial;

3. Kegiatan usaha Penyimpanan yang meliputi kegiatan penerimaan, pengumpulan, penampungan dan pengeluaran Minyak Bumi, Bahan Bakar Minyak, Bahan Bakar Gas, dan/atau Hasil Olahan pada lokasi di atas dan/atau di bawah permukaan tanah dan/atau permukaan air untuk tujuan komersial;

4. Kegiatan usaha Niaga yang meliputi kegiatan pembelian, penjualan, ekspor, impor Minyak Bumi, Bahan Bakar Minyak, Bahan Bakar Gas dan/atau Hasil Olahan, termasuk Gas Bumi melalui pipa.

Berdasarkan uraian di atas, dapat disimpulkan bahwa kegiatan hilir pada sektor migas secara umum diklasifikasi menjadi 4 (empat), yakni: pengisian (refinery), pengangkutan (transportation), penyimpanan (storage), usaha niaga (wholesale and trading) [27].

\subsubsection{Definisi dan Karakterisitik $L P G$}

Liquefied Petroleum Gas (LPG) terdiri dari unsur karbon dan hidrogen yang merupakan senyawa hidrokarbon dengan komponen utama $\mathrm{C}_{3}$ dan $\mathrm{C}_{4}$. Komposisi LPG tersebut terdiri dari senyawa propana $\mathrm{C}_{3} \mathrm{H}_{8}$, propylene atau propena $\mathrm{C}_{3} \mathrm{H}_{6}$, butana $\mathrm{C}_{4} \mathrm{H}_{10}$, butylene atau butena $\mathrm{C}_{4} \mathrm{H}_{8}$, dan sejumlah kecil ethana $\mathrm{C}_{2} \mathrm{H}_{4}$, ethylena $\mathrm{C}_{2} \mathrm{H}_{4}$, dan penthana $\mathrm{C}_{5} \mathrm{H}_{12}$. LPG adalah gas hasil produksi dari kilang migas atau pemisahan gas alam, yang komponen utamanya adalah gas propana $\left(\mathrm{C}_{3} \mathrm{H}_{8}\right)$ dan butana $\left(\mathrm{C}_{4} \mathrm{H}_{10}\right)$ yang dicairkan. LPG di Indonesia yang dikelola oleh PT Pertamina (Persero) dipasarkan dengan merk dagang ELPIJI, dan terbagi menjadi LPG Subsidi dan Non Subsidi [28].

\subsubsection{Besarnya Permintaan Gas LPG di Indonesia}

Dari segi cadangan gas global, Indonesia menempati posisi 20 besar dunia, dengan total cadangan gas sekitar 2 tcm, dengan proporsi 1,4\% cadangan gas dunia [29]. Namun, walaupun Indonesia memiliki cadangan gas dalam jumlah besar, dalam memenuhi besarnya konsumsi gas LPG dalam negeri, Indonesia masih melakukan impor. Perbandingan konsumsi, produksi dan impor gas di Indonesia dapat dilihat pada Tabel 2 di bawah ini.

Tabel 1. Konsumsi LPG di Indonesia Tahun 2012 hingga 2016

\begin{tabular}{cccc}
\hline Tahun & $\begin{array}{c}\text { Konsumsi (metrik } \\
\text { ton) }\end{array}$ & $\begin{array}{c}\text { Produksi (metrik } \\
\text { ton) }\end{array}$ & $\begin{array}{c}\text { Impor (metrik } \\
\text { ton) }\end{array}$ \\
\hline $\mathbf{2 0 1 2}$ & $5.079 .000,00$ & $2.558 .437,10$ & $2.490 .562,90$ \\
$\mathbf{2 0 1 3}$ & $5.607 .430,46$ & $3.223 .687,77$ & $2.383 .742,69$ \\
$\mathbf{2 0 1 4}$ & $6.093 .138,45$ & $3.714 .012,39$ & $2.379 .126,06$ \\
$\mathbf{2 0 1 5}$ & $6.376 .989,66$ & $4.069 .582,31$ & $2.307 .407,34$ \\
$\mathbf{2 0 1 6}$ & $6.677 .333,00$ & $4.428 .899,35$ & $2.248 .433,65$ \\
\hline
\end{tabular}

Dari Tabel 2 di atas dapat dilihat bahwa pada tahun 2016, total konsumsi gas di Indonesia mencapai 6,67 juta ton metrik. Dimana 4,42 juta ton metrik (sekitar 66,3\%) masih diimpor dan 2,24 juta ton metrik merupakan hasil produksi dalam negeri [29] Grafik yang menunjukkan permintaan dan perbandingan volume impor (warna merah) serta produksi migas di Indonesia (warna biru) tahun 2012 hingga 2016 dapat dilihat pada Gambar 2 di bawah ini. 


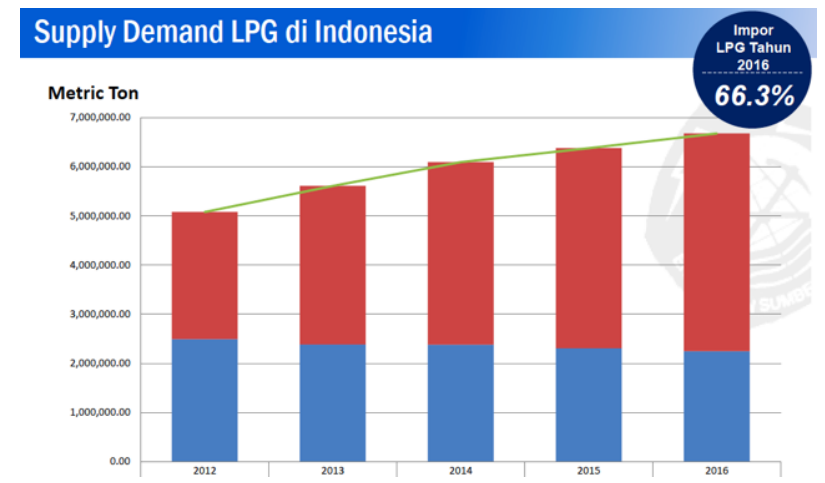

Gambar 2. Grafik Perbandingan Pemenuhan Kebutuhan Gas di Indonesia

Berdasarkan fakta penelitian pada salah satu perusahaan nasional sektor hulu migas, bahwa selama produksi dan proses pengolahan, menghasilkan limbah dalam bentuk padat, cair dan gas. Limbah cair dalam bentuk air, yang akan digunakan kembali setelah dilakukan pengolahan. Limbah padat dalam bentuk lumpur, juga dapat diolah kembali untuk kegunaan sekunder, sedangkan limbah dalam bentuk sisa gas (flare) selama ini dilakukan pembakaran di udara bebas. Flare gas adalah gas sisa yang telah terbakar melalui tumpukan cerobong untuk menghindari gas beracun seperti $\mathrm{H} 2 \mathrm{~S}$ dan $\mathrm{CO}$ yang berbahaya bagi kesehatan manusia dan lingkungan. Gas (flare) mencapai 0,58 MMSCFD sebanyak 17,05\% dari produksi atau pengolahan gas alam [30]. Pemanfaatan gas flare sebagai alternatif bahan bakar pembangkit listrik juga dapat dikatakan layak untuk diimplementasikan secara teknis dan ekonomis [31].

\subsubsection{Konversi Minyak Tanah ke LPG}

Meninjau kembali sejarah penggunaan gas di Indonesia, pada tahun 2004, mayoritas masyarakat di Indonesia masih menggunakan minyak tanah untuk keperluan memasak. Pada saat itu, minyak tanah (kerosine) dikonsumsi oleh 48 juta dari 52 juta rumah tangga dimana sebagian besar diantara mereka memiliki penghasilan rendah hingga menengah, di bawah USD 150 per bulan [32], [33]. Dikarenakan rendahnya penghasilan masyarakat di Indonesia, maka selama ini Pemerintah Indonesia memberikan subsidi terutama dalam bahan bakar dan migas. Subsidi yang diberikan Pemerintah untuk sektor bahan bakar pada tahun 2008 sekitar 18\% dari APBN, setara dengan 3,7\% PDB [34], [35].

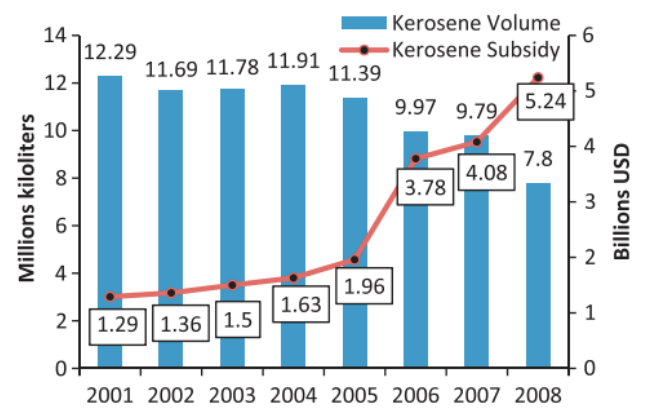

Gambar 3. Volume dan Besar Subsidi Minyak Tanah Indonesia Tahun 2001 Hingga 2008

Dari Gambar 3 di atas dapat dilihat subsidi Pemerintah atas minyak tanah meningkat dari tahun 2001 hingga 2008 sebaliknya volume yang mampu dihasilkan justru mengalami penurunan. Faktor utama penyebab permasalahan ini adalah tren kenaikan harga minyak bumi. Membengkaknya subsidi pemerintah atas minyak tanah, menyebabkan Pemerintah memutuskan untuk mengadakan program konversi minyak tanah secara signifikan ke LPG yang diluncurkan pada tahun 2007 [36],[37]. 
Pada tahun 2007, Pemerintah Indonesia meluncurkan program konversi energi dari minyak tanah ke LPG (Liquified petroleum gas). Terkait alasan mengapa LPG dijadikan sebagai sasaran konversi energi yang dipilih oleh Pemerintah Indonesia, penelitian sebelumnya yang dilakukan oleh Hanung Budya menguraikan beberapa alasan sebagai berikut [38]:

1. Meningkatkan kesehatan bagi banyak orang terutama kalangan berpendapatan rendah yang langsung terkena dampak polusi minyak tanah dalam ruangan.

2. Mengurangi emisi polutan terkait efek rumah kaca.

3. Mengurangi tekanan pada hutan alam di berbagai belahan dunia.

4. Meningkatkan penggunaan limbah pertanian.

Selain itu, LPG merupakan alternatif yang paling mudah direalisasikan dibandingkan alternatif lain seperti batubara dan gas alam. Untuk penduduk perkotaan, listrik masih dapat dijadikan sebagai alternatif minyak tanah. Namun tidak demikian dengan daerah pedesaan dimana listrik belum tersedia secara meluas [39], [40].

\subsubsection{Distribusi LPG di Indonesia}

Secara umum, rantai pasok distribusi gas terbagi menjadi 3 (tiga) bagian, yaitu upstream, midstream, dan downstream [37]. Bagian hulu (upstream) merupakan fase persiapan termasuk eksplorasi, akuisisi dan perizinan atas lahan potensial [38]. Bagian midstream terdiri dari perancangan pabrik pengolahan gas yang meliputi penghapusan asam, pemulihan sulfur, fraksinasi, dan pembuangan nitrogen [29]. Sedangkan bagian downstream (hilir) rantai pasokan gas melibatkan penyimpanan, pendistribusian, serta penjualan gas [30], [31].

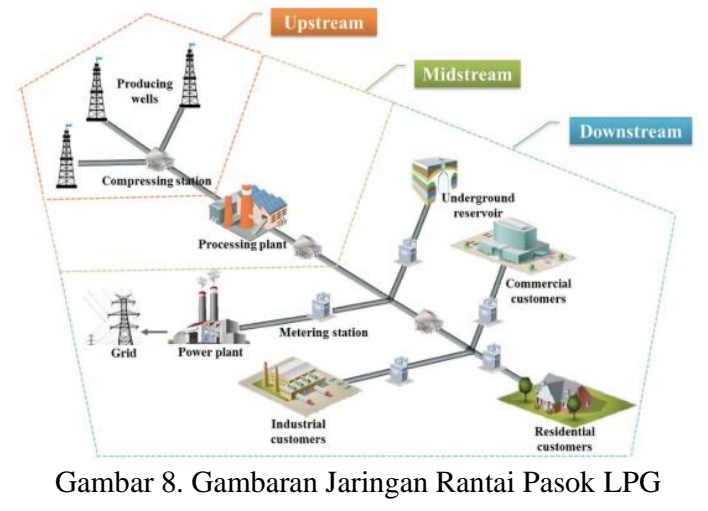

Distribusi LPG di Indonesia umumnya masih menggunakan tabung gas. Berdasarkan laporan The World Bank menunjukkan bahwa penanganan distribusi LPG melalui tabung meliputi transportasi laut, peralatan fasilitas yang diimpor, hingga manajemen tabung gas. Walaupun biaya per unit cenderung mahal, namun tabung gas 3 hingga $6 \mathrm{~kg}$ lebih mudah dalam hal pemindahan serta lebih murah dalam pengisian ulang [41].

Distribusi gas di Indonesia dimulai dari LPG Bulk Storage Tank, baik dari hasil produksi maupun impor, didistribusikan ke depot. Kemudian dari depot diturunkan ke SP(P)BE (Stasiun Pengisian dan Pengangkutan Bulk Elpiji) yang kemudian didistribusikan ke pangkalan melalui agen [42]. Agen bertugas melakukan penyimpanan sementara dan kemudian mendistribusikan tabung gas ke pangkalan yang telah terdaftar secara resmi, sehingga konsumen dapat langsung menerima tabung gas dari pangkalan distribusi gas. Keseluruhan transaksi hingga ke pangkalan terekam secara digital pada data center, sehingga mempermudah PT Pertamina (Persero) untuk memantau distribusi tabung gas di seluruh pelaku jaringan distribusinya [43]. Adapun jaringan distribusi gas di Indonesia dapat dilihat pada Gambar 4 di bawah ini. 


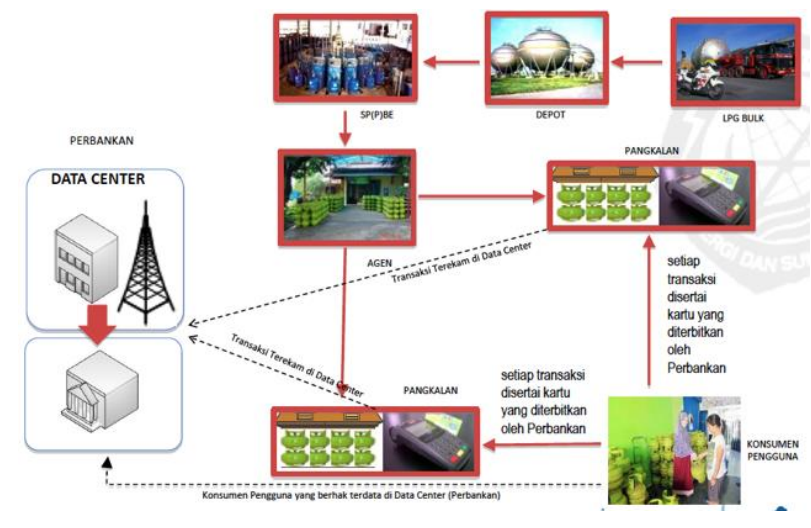

Gambar 4. Gambaran Jaringan Distribusi Gas di Indonesia

Saat ini, Indonesia memiliki 5 titik kilang (refinery), 19 depo/terminal, yang masih dominan tersebar di Pulau Sumatera dan Jawa, dengan total SPPBE untuk gas LPG $3 \mathrm{~kg}$ sebanyak 323, dan 99 SPPBE untuk gas LPG 12 dan $50 \mathrm{~kg}$. Penyimpanan dan pendistribusian dari kilang minyak ke depo/terminal masih mengandalkan floating storage sebanyak 18 unit dengan total kapasitas 220.000 MT. Peta persebaran kilang, depo/terminal di Indonesia dapat dilihat pada Gambar 5 di bawah ini.

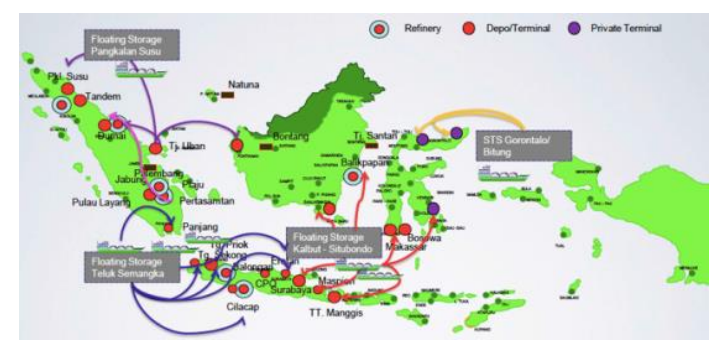

Gambar 5. Peta Persebaran Kilang, Depo/Terminal di Indonesia

Dari segi distribusi, gas LPG di Indonesia dikemas dalam beberapa jenis kemasan. Secara umum terbagi menjadi:

1. Gas Subsidi yang diperuntukkan bagi rumah tangga miskin dengan penghasilan di bawah Rp.1.500.000,00 (satu juta lima ratus ribu rupiah) dan kegiatan Usaha Kecil dan Mikro (UKM) (Perpres No. 104/2007, Peraturan Menteri ESDM No. 21 tahun 2007 tentang Penyediaan, Pendistribusian, dan Penetapan Harga Liquefied Petroleum Gas Tabung 3 Kilogram) yang dikemas dalam kemasan $3 \mathrm{~kg}$ dengan tangki berwarna hijau.

2. Gas Non Subsidi yang dikemas dalam satuan kemasan 5,5 kg dengan warna ungu untuk Bright Gas, $12 \mathrm{~kg}$ berwarna biru untuk gas ELPIJI dan ungu untuk bright gas, dan kemasan $50 \mathrm{~kg}$ dengan warna merah.

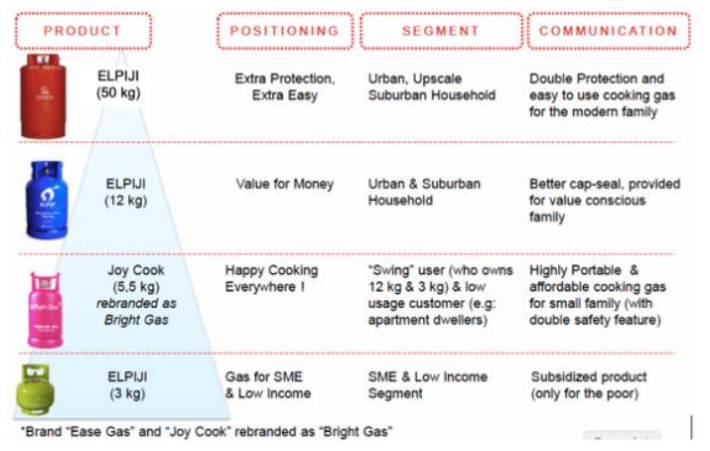

Gambar 6. Jenis Kemasan Gas Pertamina di Indonesia 


\subsubsection{Kebutuhan dan Prospek Gas LPG Indonesia di Masa Depan}

Dalam memenuhi kebutuhan gas yang diproyeksikan semakin meningkat, juga telah dilakukan riset, bahwa Indonesia masih memiliki potensi penambahan produksi dari eksplorasi. Karena, dari kondisi komitmen produksi saat ini, diprediksi akan terjadi penurunan pada tahun 2030 seperti yang ditunjukkan pada Gambar 7 di bawah ini [44].

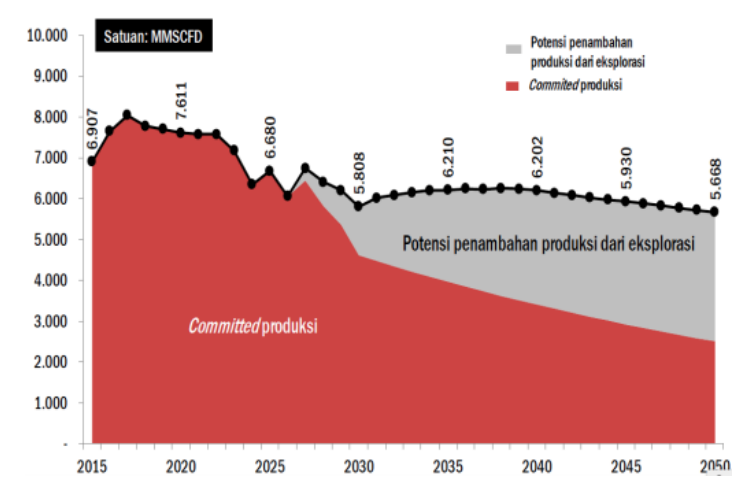

Gambar 7. Potensi Penambahan Produksi dari Eksplorasi

\subsubsection{Keberlanjutan Distribusi LPG dalam Memenuhi Krisis Energi Global}

Keberlanjutan distribusi LPG merupakan sebuah permasalahan dalam memenuhi krisis energi global [45]. Penelitian sebelumnya telah meneliti tentang integrasi antara gas alam, batubara dengan gas bumi [46]. Hasil penelitian menunjukkan bahwa tidak ada integrasi yang signifikan antara ketiga sumber energi tersebut [47]. Desain rantai pasok dan optimisasi rantai pasok atas faktor ketidakpastian telah lama dikenal sebagai suatu permasalahan yang menantang dan menjadi kunci keberhasilan suatu perindustrian migas [48], [49]. Penelitian yang dilakukan oleh Yahaya Yusuf di UK menunjukkan bahwa kelincahan/ketangkasan (agility) suatu rantai pasok diperlukan untuk menghadapi ketidakpastian dan mencapai kesigapan (responsiveness) yang sangat ditentukan oleh operasi, lingkungan, dan sektor bisnis atau industri rantai pasok tersebut [50].

Faktor kelincahan/ketangkasan (agility) merupakan salah satu faktor penentu kesigapan (responsiveness) suatu rantai pasok, yang dapat dapat dimaknai sebagai memperkaya pelanggan, memanfaatkan dampak sumber daya manusia dan informasi, bekerjasama untuk bersaing, serta menguasai perubahan dan ketidakpastian [49], [50].

Terkait kesigapan suatu rantai pasok menghadapi perubahan dan ketidakpastian, telah diuraikan beberapa fokus utama suatu rantai pasok dalam menghadapi ketidakpastian dan perubahan yaitu [51], [52]:

1. Memahami ketidakpastian antara supply dan demand,

2. Memahami karakteristik produk dan kapabilitas rantai pasok perusahaan,

3. Memastikan kesigapan rantai pasok konsisten menghadapi perubahan supply dan demand pada rantai pasok tersebut

Untuk menjamin keberlanjutan (suistanability) suatu energi, yang dapat dimaksudkan sebagai kebutuhan saat ini dapat dipenuhi tanpa mengorbankan kemampuan generasi berikut untuk memenuhi kebutuhan secara mandiri, maka perlu dilakukan perubahan pola distribusi menghadapi perubahan iklim yang signifikan [53]. Seperti yang telah dilakukan yakni beberapa perubahan multi-stages pada pola distribusi dalam rantai pasok gas, mulai dari transportasi, penggunaan, pembuangan, serta pembangkitan dan transmisi energi terkait distribusi tersebut [54].

Penyajian model matematis pada setiap tingkat rantai pasokan gas alam dalam meminimalisasi biaya ekonomi yang timbul serta dampak lingkungan, akan membantu menciptakan manajemen rantai pasokan gas yang berkelanjutan dan ramah lingkungan [55], [56].

Penelitian terdahulu di Ireland juga menunjukkan bahwa analisis rantai nilai pada suatu jaringan rantai pasok diperlukan dalam mengidentifikasi parameter ekonomi yang paling penting untuk dijadikan tolok ukur kelayakan suatu rantai pasok dari segi ekonomis, yang diwakili oleh variabel biaya kapital dan biaya operasional [57].

Rantai pasok LPG itu sendiri dimulai dari eksplorasi dan pengembangan lahan potensi gas bumi [58]. Kemudian, diikuti oleh komponen rantai pasokan yang kompleks serta membutuhkan investasi besar setelah eksplorasi yakni ekstraksi, produksi, transportasi, penyimpanan dan distribusi [59]. 
Terkait prospek gas global selama beberapa tahun ke depan, International Energy Agency memperkirakan bahwa lebih dari $40 \%$ dari komunitas ataupun keluarga yang baru memperoleh akses energi rumah tangga modern, akan menggunakan LPG, terutama di area perkotaan [60]. LPG akan dijadikan sebagai suatu fase transisi terutama rumah tangga untuk beralih dari metode pemanasan konvensional menuju pemanasan dengan menggunakan energi listrik [61], [62].

\section{Kesimpulan dan Saran}

Kesimpulan yang diperoleh setelah menyelesaikan penelitian ini adalah sebagai berikut.

1. Peningkatan permintaan terhadap LPG dalam memenuhi kebutuhan energi global terjadi di hampir seluruh dunia. Krisis energi global dan peningkatan permintaan LPG diproyeksikan akan terus menerus terjadi hingga tahun 2050.

2. Program konversi energi Pemerintah Indonesia yang diluncurkan pada tahun 2004 terkait konversi pemenuhan kebutuhan energi rumah tangga dari minyak tanah menuju LPG yang dinamakan sebagai From Kerosine to LPG berpengaruh signifikan terhadap peningkatan kebutuhan LPG di Indonesia. Namun masyarakat Indonesia saat ini masih cenderung mengkonsumsi gas subsidi $3 \mathrm{~kg}$ yang dikhususkan untuk kalangan menengah ke bawah yang berpenghasilan kurang dari 1,5 juta per bulan dalam memenuhi kebutuhan energi rumah tangga.

3. Peningkatan kebutuhan suatu komoditas akan berpengaruh terhadap pola distribusinya. Hal ini disebabkan perlu penyesuaian dari segi kesigapan (responsiveness) dan kelincahan (agility) rantai suplai tersebut dalam memenuhi peningkatan ataupun perubahan kuantitas permintaan pasar atas komoditas tersebut.

4. Terkait distribusi LPG secara umum terbagi menjadi 3 (tiga) bagian utama yakni upstream mulai dari eksplorasi , midstream dan downstream hingga LPG tersebut didistribusikan mencapai konsumen akhir. Distribusi downstream yang digunakan di Indonesia saat ini adalah distribusi dengan menggunakan tabung gas, yang dikemas dalam kemasan $3 \mathrm{~kg}, 5.5 \mathrm{~kg}, 12 \mathrm{~kg}$ dan $50 \mathrm{~kg}$.

5. Untuk menjamin keberlanjutan distribusi LPG di Indonesia, perlu dilakukan evaluasi dan perubahan pola distribusi dalam menghadapi peningkatan permintaan LPG. Perancangan ulang jaringan distribusi LPG perlu memahami karakteristik produk dan kapabilitas Perusahaan dalam melakukan distribusi, serta memahami kesigapan setiap pelaku rantai pasok tersebut dalam menghadapi peningkatan permintaan.

\section{Acknowledgement}

Penulis berterimakasih kepada Program Studi Magister Teknik Industri dan Doktor Ilmu Teknik Industri Universitas Sumatera Utara sebagai institusi yang menaungi Penulis dalam melakukan penelitian.

\section{Referensi}

[1] Pertamina; World LP Gas Association, “Kerosene to LP Gas Conversion Programme in Indonesia," 2015.

[2] H. Budya and M. Yasir Arofat, "Providing cleaner energy access in Indonesia through the megaproject of kerosene conversion to LPG," Energy Policy, vol. 39, no. 12, pp. 7575-7586, 2011.

[3] R. K. Andadari, P. Mulder, and P. Rietveld, "Energy poverty reduction by fuel switching. Impact evaluation of the LPG conversion program in Indonesia," Energy Policy, vol. 66, pp. 436-449, 2014.

[4] S. V. Ravan, "Impact of LPG on Indian Economy," Prime Int. Res. J., vol. 1, no. 4, 2017.

[5] D. Asamoah, R. Amoakohene, and E. Adiwokor, "Analysis of Liquefied Petroleum Gas (LPG) Shortage in Ghana: A Case of the Ashanti Region,” Int. J. Bus. Adm., vol. 3, no. 5, pp. 89-98, 2012.

[6] H. Zhao, H. Zhao, X. Han, Z. He, and S. Guo, "Economic growth, electricity consumption, labor force and capital input: A more comprehensive analysis on North China using panel data," Energies, vol. 9, no. 11, pp. 1-21, 2016.

[7] M. Behname, "The relationship between Market Size , Inflation and Energy," 2013.

[8] Deloitte Insight Report, “The shed of the future E-commerce: its impact on warehouses,” Deloitte Insight Rep., 2014.

[9] N. Demirtaş and U. R. Tuzkaya, "Strategic Planning of Layout of the Distribution Center: an Approach for Fruits and Vegetables Hall," Procedia - Soc. Behav. Sci., vol. 58, pp. 159-168, 2012.

[10] A. Da Cunha Reis, C. Gomes de Souza, N. Nogueira da Costa, G. H. Cordeiro Stender, P. Senna Vieira, and N. Domingues Pizzolato, "Warehouse design: a systematic literature review," Brazilian J. Oper. Prod. Manag., vol. 14, no. 4, p. 542, 2017.

[11]P. Everaert, W. Bruggeman, G. Sarens, S. R. Anderson, and Y. Levant, "Cost modeling in logistics using time-driven ABC: Experiences from a wholesaler,” Int. J. Phys. Distrib. Logist. Manag., vol. 38, no. 3, pp. 172-191, 2008.

[12]B. Minten and S. Kyle, "The effect of distance and road quality on food collection, marketing margins, and traders' wages: Evidence from the former Zaire,” J. Dev. Econ., vol. 60, no. 2, pp. 467-495, 1999.

[13]Z. Yongsheng, H. Botang, X. Ping, and L. Zhenjian, "Routing-optimization of City Logistics Distribution under Traffic Restrict Conditions," J. Wuhan Univ. Technol. (Transportation Sci. Eng., 2004.

[14]C. KuanMin and W. Yuping, "Distribution Characteristics and Countermeasures of Traffic Accidents in Rural Road," J. Traffic Transp. 
Eng., vol. 3, no. Ictim, pp. 552-559, 2016.

[15]A. Ambituuni, J. M. Amezaga, and D. Werner, "Risk assessment of petroleum product transportation by road: A framework for regulatory improvement," Saf. Sci., vol. 79, pp. 324-335, 2015.

[16]V. Jayaraman, “Transportation, facility location and inventory issues in distribution network design: An investigation,” Int. J. Oper. Prod. Manag., vol. 18, no. 5, pp. 471-494, 1998.

[17] Sinulingga, Sukaria "Metodologi Penelitian" USU Press, 2015

[18] BP Plc (2018) 'Statistical Review of World Energy, Natural Gas Consumption' https:/www.bp.com/en/global/corporate/natural-gas.html/

[19] J. Li, X. Dong, J. Shangguan, and M. Hook, "Forecasting the growth of China's natural gas consumption," Energy, vol. 36, no. 3, pp. 1380$1385,2011$.

[20]DECC, “The Future of Heating : Meeting the challenge,” Decc, no. March, 2013.

[21] a. Venkatesh, P. Jaramillo, W. M. Griffin, and M. H.S., "Uncertainty in life cycle greenhouse gas emissions from United States natural gas end users and its effects on policy," Environ. Sci. Technol., vol. 45, pp. 8182-8189, 2011.

[22]U. E. I. A. EIA, “Annual Energy Outlook 2012 with Projections to 2035,” Retin. Fourth Ed., vol. 3-3, pp. 2035-2070, 2012.

[23]F. E. Boran, "Forecasting natural gas consumption in Turkey using grey prediction," Energy Sources, Part B Econ. Plan. Policy, vol. 10, no. 2, pp. 208-213, 2015.

[24]A. Mostafaeipour and N. Mostafaeipour, "Renewable energy issues and electricity production in Middle East compared with Iran," Renew. Sustain. Energy Rev., vol. 13, no. 6-7, pp. 1641-1645, 2009.

[25]S. A. Solarin and M. Shahbaz, "Natural gas consumption and economic growth: The role of foreign direct investment, capital formation and trade openness in Malaysia," Renew. Sustain. Energy Rev., vol. 42, pp. 835-845, 2015.

[26]M. H. Syukur, "Penggunaan Liquified Petroleum Gases (LPG): Upaya Mengurangi Kecelakaan Akibat LPG,” Forum Teknol., vol. 01, no. 2, pp. 1-14, 2011.

[27]A. Demirbas, "Fuel Properties of Hydrogen, Liquefied Petroleum Gas ( LPG ), and Compressed Natural Gas ( CNG ) for Transportation Fuel Properties of Hydrogen , Lique ed Petroleum Gas ( LPG ), and Compressed Natural Gas ( CNG ) for Transportation," Energy Sources, vol. 8312, no. March 2014, pp. 37-41, 2010.

[28]J. Hidayati, N. Silviana, and R. Matondang, "Increased productivity through waste reduction effort in oil and gas company," IOP Conf. Ser. Mater. Sci. Eng., vol. 309, p. 012010, 2018.

[29]Y. Petri, H. Juliza, and N. Humala, "Technical and economic analysis use of flare gas into alternative energy as a breakthrough in achieving zero routine flaring,” Int. J. Qual. Res., pp. 1-10, 2017.

[30] Pertamina; World LP Gas Association, "Kerosene to LP Gas Conversion Programme in Indonesia," 2015.

[31]H. Budya and M. Yasir Arofat, "Providing cleaner energy access in Indonesia through the megaproject of kerosene conversion to LPG," Energy Policy, vol. 39, no. 12, pp. 7575-7586, 2011.

[32] The World Bank, "The Role of Liquefied Petroleum Gas in Reducing Energy Poverty. The World Bank. Extractive Industries for Development Series," no. December, 2011.

[33]L. J. Bachmeier and J. M. Griffin, "Testing for Market Integration Crude Oil , Coal , and Natural Gas Published by: International Association for Energy Economics," vol. 27, no. 2, pp. 55-71, 2016.

[34]L. G. Papageorgiou, "Supply chain optimisation for the process industries: Advances and opportunities," Comput. Chem. Eng., vol. 33, no. 12, pp. 1931-1938, 2009.

[35]J. Gosling, L. Purvis, and M. M. Naim, "Supply chain flexibility as a determinant of supplier selection,” Int. J. Prod. Econ., vol. 128, no. 1, pp. 11-21, 2010.

[36] Y. Y. Yusuf, A. Gunasekaran, A. Musa, M. Dauda, N. M. El-berishy, and S. Cang, "Int . J . Production Economics A relational study of supply chain agility , competitiveness and business performance in the oil and gas industry," Intern. J. Prod. Econ., no. 2000, pp. 1-13, 2012.

[37]V. Jain, L. Benyoucef, and S. G. Deshmukh, "A new approach for evaluating agility in supply chains using Fuzzy Association Rules Mining," Eng. Appl. Artif. Intell., vol. 21, no. 3, pp. 367-385, 2008.

[38]S. M. Wagner, P. T. Grosse-ruyken, and F. Erhun, "The link between supply chain fit and financial performance of the firm \&," J. Oper. Manag., vol. 30, no. 4, pp. 340-353, 2012.

[39] S. Chopra and P. Meindl, Supply Chain Management. 2013.

[40]J. Bekkering, A. A. Broekhuis, and W. J. T. van Gemert, "Optimisation of a green gas supply chain - A review," Bioresour. Technol., vol. 101, no. 2, pp. 450-456, 2010.

[41]E. L. Plambeck, "Reducing greenhouse gas emissions through operations and supply chain management," Energy Econ., vol. 34, pp. S64S74, 2012.

[42]A. Azadeh, Z. Raoo, and M. Zarrin, "Journal of Natural Gas Science and Engineering A multi-objective fuzzy linear programming model for optimization of natural gas supply chain through a greenhouse gas reduction approach," vol. 26, pp. 702-710, 2015.

[43]M. Fodstad, K. T. Uggen, F. R. SINTEF, A. G. Lium, G. Stremersch, and S. Hecq, "LNGScheduler: A rich model for coordinating vessel routing, inventories and trade in the LNG supply chain LNGScheduler : a rich model for coordinating vessel routing, inventories and trade in the," no. June 2014, 2010.

[44]J. Gao and F. You, "Deciphering and Handling Uncertainty in Shale Gas Supply Chain Design and Optimization: Novel Modeling Framework and Computationally Efficient Solution Algorithm," vol. 61, no. 11, 2015.

[45]C. He and F. You, "Towards More Cost-Effective and Greener Chemicals Production from Shale Gas by Integrating with Bioethanol Dehydration: Novel Process Design and simulation-based Optimization,” Can. Vet. J., vol. 59, no. 6, pp. 663-667, 2018.

[46]C. He and F. You, "Shale gas processing integrated with ethylene production: Novel process designs, exergy analysis, and techno-economic analysis," Ind. Eng. Chem. Res., vol. 53, no. 28, pp. 11442-11459, 2014.

[47]N. R. Harding, "Application of Stochastic Prospect Analysis for Shale Gas Reservoirs," SPE Russ. Oil Gas Tech. Conf. Exhib., no. October, pp. 28-30, 2008.

[48]M. Kojima, “The Role of Liquefi ed Petroleum,” no. December, 2011

[49]P. E. Dodds and W. McDowall, “The future of the UK gas network," Energy Policy, vol. 60, pp. 305-316, 2013. 
[50]R. K. Andadari, P. Mulder, and P. Rietveld, "Energy poverty reduction by fuel switching. Impact evaluation of the LPG conversion program in Indonesia,” Energy Policy, vol. 66, pp. 436-449, 2014.

[51]Z. Wadud, H. S. Dey, M. A. Kabir, and S. I. Khan, "Modeling and forecasting natural gas demand in Bangladesh,” Energy Policy, vol. 39, no. 11, pp. 7372-7380, 2011

[52]M. Melikoglu, "Vision 2023: Forecasting Turkey’s natural gas demand between 2013 and 2030,” Renew. Sustain. Energy Rev., vol. 22, pp. 393-400, 2013.

[53]B. Zeng and C. Li, "Forecasting the natural gas demand in China using a self-adapting intelligent grey model," Energy, vol. 112, pp. 810$825,2016$.

[54]S. Kumar, H. T. Kwon, K. H. Choi, J. Hyun Cho, W. Lim, and I. Moon, "Current status and future projections of LNG demand and supplies: A global prospective," Energy Policy, vol. 39, no. 7, pp. 4097-4104, 2011.

[55]W. J. Smith, "Projecting EU demand for natural gas to 2030: A meta-analysis," Energy Policy, vol. 58, pp. 163-176, 2013.

[56]N. Gupta, A. Swarnkar, and K. R. Niazi, "Distribution network reconfiguration for power quality and reliability improvement using Genetic Algorithms,” Int. J. Electr. Power Energy Syst., vol. 54, pp. 664-671, 2014.

[57]M. Farsi, M. Filippini, and M. Kuenzle, "Cost efficiency in the Swiss gas distribution sector," Energy Econ., vol. 29, no. 1, pp. 64-78, 2007.

[58] V. K. Pantangi, S. C. Mishra, P. Muthukumar, and R. Reddy, "Studies on porous radiant burners for LPG (liquefied petroleum gas) cooking applications,” Energy, vol. 36, no. 10, pp. 6074-6080, 2011.

[59]P. Fabbri, G. Fraquelli, and R. Giandrone, “Costs, technology and ownership of gas distribution in Italy,” Manag. Decis. Econ., vol. 21, no. 2, pp. 71-81, 2000.

[60]M. R. Haghifam and M. Manbachi, "Reliability and availability modelling of combined heat and power (CHP) systems,” Int. J. Electr. Power Energy Syst., vol. 33, no. 3, pp. 385-393, 2011.

[61]L. Raslavičius, A. Keršys, S. Mockus, N. Keršiene, and M. Starevičius, "Liquefied petroleum gas (LPG) as a medium-term option in the transition to sustainable fuels and transport," Renew. Sustain. Energy Rev., vol. 32, pp. 513-525, 2014.

[62]T. Krause, G. Andersson, K. Frohlich, and A. Vaccaro, "[Coping with everyday stress in different problem areas- comparison of clinically referred and healthy adolescents].," Coping mit Alltagsstress Verschied. Probl. Vergleich Klin. auffalliger und gesunder Jugendlicher., vol. 41, no. 5, pp. 295-297, 2013. 